\title{
Carbachol- and Elevated $\mathrm{Ca}^{2+}$-induced Translocation of Functionally Active Protein Kinase $\mathbf{C}$ to the Brush Border of Rabbit lleal $\mathrm{Na}^{+}$Absorbing Cells
}

\author{
Michael E. Cohen, John Wesolek, Jennifer McCullen, Krystyna Rys-Sikora, Steve Pandol," Richard P. Rood, \\ Geoffrey W. G. Sharp, ${ }^{\ddagger}$ and Mark Donowitz \\ Departments of Medicine and Physiology, The Johns Hopkins University School of Medicine, Baltimore, Maryland 21205, and Tufts \\ University School of Medicine and New England Medical Center, Boston, Massachusetts 02111; *Department of Medicine, Veterans \\ Administration and University of California, San Diego, California 92131; and ${ }^{\ddagger}$ Department of Pharmacology, New York State College \\ of Veterinary Medicine, Cornell University, Ithaca, New York 14853
}

\begin{abstract}
Protein kinase $C$ is involved in mediating the effects of elevated $\mathrm{Ca}^{2+}$ in ileal villus $\mathrm{Na}^{+}$absorbing cells to inhibit $\mathrm{NaCl}$ absorption. The present studies were undertaken to understand the mechanism by which this occurs. The effects of carbachol and the calcium ionophore A23187, agents which elevate intracellular $\mathrm{Ca}^{2+}$ and inhibit $\mathrm{NaCl}$ absorption in ileal villus cells, were studied. Carbachol treatment of villus cells caused a rapid decrease in protein kinase $\mathbf{C}$ activity in cytosol, with an accompanying increase in microvillus membrane $C$ kinase. Exposure of the villus cells to calcium ionophore also caused a quantitatively similar decrease in cytosol $\mathrm{C}$ kinase and increase in $\mathrm{C}$ kinase activity in the microvillus membrane. This increase caused by carbachol and $\mathrm{Ca}^{2+}$ ionophore was specific for the microvillus membrane. In fact, $30 \mathrm{~s}$ and $10 \mathrm{~min}$ after exposure of the cells to carbachol, basolateral membrane protein kinase $C$ decreased, in a time-dependent manner; whereas $10 \mathrm{~min}$ of $\mathrm{Ca}^{2+}$ ionophore exposure did not alter basolateral $\mathrm{C}$ kinase. Exposure of villus cells to $\mathrm{Ca}^{2+}$ ionophore or carbachol caused similar increases in microvillus membrane diacylglycerol content. As judged by the ability to inhibit $\mathrm{Na}^{+} / \mathrm{H}^{+}$exchange measured in ileal villus cell brush border membrane vesicles, the protein kinase $\mathbf{C}$ which translocated to the microvillus membrane was functionally significant. Inhibition of $\mathrm{Na}^{+} / \mathrm{H}^{+}$exchange required $A T P$ and was reversed by the protein kinase $C$ antagonist $\mathrm{H}-7$. In conclusion, the effect of carbachol and $\mathrm{Ca}^{2+}$ ionophore in regulation of ileal $\mathrm{NaCl}$ absorption is associated with an increase in microvillus membrane diacylglycerol content and functionally active protein kinase $\mathrm{C}$. The effects of both carbachol and $\mathrm{Ca}^{2+}$ ionophore are different on brush border and basolateral membrane distribution of protein kinase C. (J. Clin. Invest. 1991. 88:855-863.) Key words: $\mathrm{Ca}^{2+} \cdot$ protein kinase $\mathrm{C} \cdot \mathrm{Na}^{+} / \mathrm{H}^{+}$exchange $\bullet \mathrm{Na}^{+}$absorption
\end{abstract}

\section{Introduction}

Calcium plays a major regulatory role in $\mathrm{Na}^{+}$absorption by the rabbit ileum (1). Drugs or hormones which raise cytosol free

Address correspondence to Mark Donowitz, M.D., Chief, GI Unit, The Johns Hopkins University School of Medicine, 417 Hunterian Building, 725 N. Wolfe St., Baltimore, MD 21205.

Received for publication 26 April 1990 and in revised form 16 May 1991.

J. Clin. Invest.

(c) The American Society for Clinical Investigation, Inc.

$0021-9738 / 91 / 09 / 0855 / 09 \$ 2.00$

Volume 88, September 1991, 855-863
$\mathrm{Ca}^{2+}$ levels $\left(\left[\mathrm{Ca}^{2+}\right]_{\mathrm{i}}\right)$ in ileal $\mathrm{Na}^{+}$absorbing epithelial cells inhibit $\mathrm{NaCl}$ absorption, whereas those which lower $\left[\mathrm{Ca}^{2+}\right]_{\mathrm{i}}$ stimulate $\mathrm{NaCl}$ absorption (1). It is believed that the $\mathrm{NaCl}$ absorptive process is made up of two neutral exchangers, $\mathrm{Na}^{+} / \mathrm{H}^{+}$and $\mathrm{Cl}^{-} / \mathrm{HCO}_{3}^{-}$, acting in parallel in the brush border membrane of ileal villus epithelial cells. Calcium regulates $\mathrm{NaCl}$ absorption by affecting the activity of the $\mathrm{Na}^{+} / \mathrm{H}^{+}$exchanger (2). The regulation by $\mathrm{Ca}^{2+}$ is somewhat complex. Basal $\mathrm{Na}^{+}$absorption is regulated by an endogenous brush border membrane $\mathrm{Ca}^{2+} /$ calmodulin-dependent protein kinase, which is a form of $\mathrm{CaM}$ kinase II; however, the effects of elevating $\left[\mathrm{Ca}^{2+}\right]_{\mathrm{i}}$ above basal are not blocked by calmodulin inhibitors, including the naphthalenesulfonamide W13. Rather, the effects are mediated via protein kinase $\mathrm{C}$ and are reversed by the protein kinase $\mathrm{C}$ inhibitor, the isoquinolenesulfonamide $\mathrm{H}-7$ (3).

The purpose of the present studies was to characterize the mechanism by which protein kinase $\mathrm{C}$ mediates the effect of elevated $\left[\mathrm{Ca}^{2+}\right]_{i}$ on ileal $\mathrm{NaCl}$ absorption and $\mathrm{Na}^{+} / \mathrm{H}^{+}$exchange. Activation of protein kinase $\mathrm{C}$ has been shown to be associated in some cells with translocation from cytosol to membranes (for examples, see references 4-7). In the present work, we investigated the effect of carbachol and the calcium ionophore $\mathrm{A} 23187$, two agents which inhibit ileal $\mathrm{NaCl}$ absorption by elevating $\left[\mathrm{Ca}^{2+}\right]_{i}$, on protein kinase $\mathrm{C}$ translocation.

\section{Methods}

Distal ileum from 2-2.5-kg New Zealand White male rabbits was used for all experiments. Unless otherwise indicated, all procedures were carried out at $0-4^{\circ} \mathrm{C}$. Rabbits were sacrificed by nembutal overdose. Ileum was removed and flushed free of its contents with $0.9 \%$ saline, followed by $0.9 \%$ saline containing $50 \mu \mathrm{g} / \mathrm{ml}$ phenylmethylsulfonylfluoride (PMSF), $25 \mu \mathrm{g} / \mathrm{ml}$ aprotinin, and $1 \mu \mathrm{M}$ indomethacin. In most studies, ileal sheets were exposed in vitro to secretagogues, with biochemical studies done on lightly scraped ileal mucosa. In a few studies, isolated ileal epithelial cells were initially obtained and then exposed to secretagogues.

Scraped ileal mucosa. Ileal segments of $\sim 20 \mathrm{~cm}$ were cut lengthwise and incubated for the indicated times in $200 \mathrm{ml}$ of Ringer's-bicarbonate gassed with $95 \% \mathrm{O}_{2} / 5 \% \mathrm{CO}_{2}$ at $37^{\circ} \mathrm{C}$, containing $1 \mu \mathrm{M}$ indomethacin. The incubation medium contained either $1 \mu \mathrm{M}$ carbachol, 1 $\mu \mathrm{M}$ calcium ionophore $\mathrm{A} 23187$, or an equivalent volume of Ringer'sbicarbonate (control). After incubation in Ringer's-bicarbonate the ileal segments were chilled, and mucosa was removed by lightly scraping with a glass slide. This procedure yields predominantly villus cells. Homogenization was with a polytron homogenizer in 10 vol of $2 \mathrm{mM}$ DTT, $1 \mathrm{mM}$ EGTA/1.006 mM CaCl 2 (free $\left.\mathrm{Ca}^{2+}=10 \mu \mathrm{M}\right), 50 \mu \mathrm{g} / \mathrm{ml}$ PMSF, $1 \mu \mathrm{g} / \mathrm{ml}$ phosphoramidone, $25 \mu \mathrm{g} / \mathrm{ml}$ aprotinin, $0.01 \%$ leupeptin, $20 \mathrm{mM}$ Tris, $\mathrm{pH}$ 7.5. The homogenization consisted of $1010-\mathrm{s}$ bursts with 20 -s cooling intervals between bursts. The homogenate was centrifuged at $1,900 \mathrm{~g}$ for $10 \mathrm{~min}$ in a model SS-34 rotor (Sorvall Instru- 
ments, Newton, CT). The pellet was used to prepare microvillus membranes by a modification of a previously described method (8) and the supernatant was used to prepare cytosol.

The pellets from the first centrifugation were resuspended in $2 \mathrm{mM}$ DTT, $1 \mathrm{mM} \mathrm{EGTA} / 1.006 \mathrm{mM} \mathrm{CaCl}_{2}, 20 \mathrm{mM}$ Tris, $\mathrm{pH} 7.5$, by homogenization with a Dounce homogenizer (20 strokes, loose pestle), and centrifuged at $1,075 \mathrm{~g}$ for $10 \mathrm{~min}$. The pellets were resuspended by vortexing in the same buffer and washed three times at $1,075 \mathrm{~g}$ for 10 min before being resuspended in $250 \mathrm{mM}$ sorbitol, $2 \mathrm{mM}$ DTT, $1 \mathrm{mM}$ EGTA/1.006 mM CaCl $2,20 \mathrm{mM}$ Tris, pH 7.5, and centrifuged at $25,000 \mathrm{~g}$ for $20 \mathrm{~min}$. They were then resuspended in the same buffer by homogenization with a motor-driven glass-Teflon homogenizer for 1 $\min . \mathrm{MgSO}_{4}$ was added, with stirring, to the membrane suspension to a final concentration of $10 \mathrm{mM}$ and the mixture was allowed to stand for $10 \mathrm{~min}$ and then centrifuged at $5,000 \mathrm{~g}$ for $10 \mathrm{~min}$. The pellets were discarded and the supernatants were centrifuged at $25,000 \mathrm{~g}$ for $20 \mathrm{~min}$. The pellets were then resuspended in the sorbitol buffer and the magnesium precipitation steps were repeated. The final pellets, representing microvillus membrane, were resuspended in $10 \%$ glycerol, $2 \mathrm{mM} \mathrm{DTT}$, $20 \mathrm{mM}$ Tris, $\mathrm{pH} 7.5$, and stored at $-80^{\circ} \mathrm{C}$.

The supernatants from the initial centrifugation were centrifuged at $171,000 \mathrm{~g}$ for $1 \mathrm{~h}$ in a model 70Ti rotor (Beckman Instruments, Inc., Fullerton, CA). The pellets were discarded, and glycerol was added to the supernatants to a final concentration of $10 \%$, and this cytosol fraction was stored at $-80^{\circ} \mathrm{C}$.

Purified basolateral membranes were prepared by a modification of the method of Scalera et al. (9). $4 \mathrm{~g}$ of scraped ileal mucosa were homogenized in $80 \mathrm{ml}$ of $2 \mathrm{mM}$ DTT, $1 \mathrm{mM}$ EGTA, $1.006 \mathrm{mM} \mathrm{CaCl}_{2}, 50$ $\mathrm{mg} / \mathrm{ml} \mathrm{PMSF}, 1 \mathrm{mg} / \mathrm{ml}$ phosphorhamidone, $0.01 \%$ leupeptin, $25 \mu \mathrm{g} /$ $\mathrm{ml}$ aprotinin, $20 \mathrm{mM}$ Tris, $\mathrm{pH} 7.5$, with a polytron homogenizer (two 10 -s bursts at top speed, six 10 -s bursts at $70 \%$ of top speed). The homogenate was centrifuged at $750 \mathrm{~g}$ for $10 \mathrm{~min}$ and the pellets discarded. The supernatant was centrifuged at $23,400 \mathrm{~g}$ for $20 \mathrm{~min}$. The fluffy layer of the pellets was resuspended in $250 \mathrm{mM}$ sucrose, $2 \mathrm{mM}$ DTT, 1 mM EGTA, $1.006 \mathrm{mM} \mathrm{CaCl}_{2}, 20 \mathrm{mM}$ Tris, pH 7.5 (buffer A) by gentle swirling and homogenized with five strokes of a Dounce homogenizer. The suspension was again centrifuged at $23,400 \mathrm{~g}$ for 20 $\mathrm{min}$ and the fluffy layer of the pellet resuspended in buffer $A$ containing $14 \%$ Percoll. This suspension was centrifuged at $47,800 \mathrm{~g}$ for $38 \mathrm{~min}$ in a Sorvall Instruments model SS-34 rotor and fractionated from the top by pumping $60 \%$ (wt/vol) sucrose to the bottom of the tube. $2 \mathrm{vol}$ of buffer A containing $0.9 \% \mathrm{NaCl}$ were added to each gradient fraction and the fractions centrifuged at $246,800 \mathrm{~g}$ for $1 \mathrm{~h}$. Pellets were resuspended in $2 \mathrm{mM}$ DTT, $10 \%$ glycerol, $20 \mathrm{mM}$ Tris, pH 7.4, and stored at $-80^{\circ} \mathrm{C}$. The basolateral band was located by assaying each fraction for $\mathrm{Na} / \mathrm{K}$ ATPase.

Isolated ileal villus cells. Because basolateral membranes prepared from scraped ileal mucosa could be contaminated with plasma membranes from nonepithelial cells, isolated villus cells were initially prepared and then both microvillus membranes and basolateral membranes purified. The dissociated ileal villus cells were prepared as we have described (10), using a modification of the citrate/distention technique of Weiser (11). The first three fractions were utilized, which correspond to the fractions having highest sucrase activity (10). The dissociated cells were pelleted by centrifugation at $1,200 \mathrm{~g}, 10 \mathrm{~min}$, $4^{\circ} \mathrm{C}$, resuspended in Ringer's-bicarbonate and preincubated with gassing with $95 \% \mathrm{O}_{2} / 5 \% \mathrm{CO}_{2}$ for $15 \mathrm{~min}$. Carbachol was then added for $30 \mathrm{~s}$ or $10 \mathrm{~min}$. The incubation was stopped by rapidly chilling the cells, then centrifuging the cells at $1,200 \mathrm{~g}, 10 \mathrm{~min}, 4^{\circ} \mathrm{C}$, and resuspending the cells in the same homogenization buffer described for the scraped ileal mucosa studies. Microvillus and basolateral membranes were prepared from dissociated cells by the same methods used for scraped ileal mucosa, described above, except in preparation of basolateral membranes a Dounce homogenizer with loose pestle (20 strokes) was used instead of a polytron and the homogenization solution was $\mathrm{pH} 8.3$.

Partial purification of protein kinase $C$. Leupeptin was added to aliquots of each subcellular fraction to a final concentration of $0.01 \%$ and Triton X-100 was added to a final concentration of $0.3 \%$. The mixtures were vortexed and incubated at $0^{\circ} \mathrm{C}$ for $30 \mathrm{~min}$, and then centrifuged at $\sim 12,000 \mathrm{~g}$ in a microfuge for $10 \mathrm{~min}$. The pellets were discarded and the supernatants were mixed with DE-52 cellulose (Whatman Inc., Clifton, NJ), by vortexing for $10 \mathrm{~min}$. The gel slurries were centrifuged in the microfuge for $5 \mathrm{~min}$ and the supernatants discarded. The DE-52 fractions were washed three times with $0.5 \mathrm{mM}$ EGTA, 5 mM EDTA, $50 \mathrm{mM}$ DTT, $20 \mathrm{mM}$ Tris, pH 7.5. The washed gel was then mixed with the same buffer containing $100 \mathrm{mM} \mathrm{NaCl}$. The gel slurry was vortexed for $10 \mathrm{~min}$ and then centrifuged at approximately $12,000 \mathrm{~g}$ in a microfuge for $5 \mathrm{~min}$. The gel was discarded and the supernatant used as the partially purified $\mathrm{C}$ kinase.

Protein kinase $C$ assay. Protein kinase activity was determined by a histone IIIS phosphorylation assay and, in several studies, the amount of protein kinase $\mathrm{C}$ also was determined by phorbol dibutyrate binding.

Histone IIIS phosphorylation assay. The assay mixture contained $10 \mathrm{mM} \mathrm{MgCl} 2,2 \mathrm{mg} / \mathrm{ml}$ histone IIIS, $1.1 \mathrm{mM} \mathrm{CaCl}_{2}, 1.0 \mathrm{mM}$ EGTA (free $\mathrm{Ca}^{2+}=100 \mu \mathrm{M}$ ), $40 \mu \mathrm{g} / \mathrm{ml}$ phosphatidylserine (PS), $10 \mu \mathrm{M}$ phorbol dibutyrate, $5 \mu \mathrm{M} \gamma\left[{ }^{32} \mathrm{P}\right] \mathrm{ATP}(6.25 \mathrm{Ci} / \mathrm{mol}), 2 \mathrm{mM}$ DTT, $0.01 \%$ leupeptin, $20 \mathrm{mM}$ Tris, pH 7.5 in a total volume of $100 \mu \mathrm{l}$. The reaction was started by addition of the partially purified enzyme and allowed to proceed for $10 \mathrm{~min}$ at $30^{\circ} \mathrm{C}$ before termination by addition of $1 \mathrm{ml}$ of $10 \%$ TCA, $0.2 \%$ sodium pyrophosphate, and boiling for $10 \mathrm{~min}$. The precipitates were collected on Whatman Inc. GF/A filters and washed with $24 \mathrm{ml}$ of $10 \% \mathrm{TCA}, 0.2 \%$ sodium pyrophosphate, and radioactivity determined in a scintillation counter. $C$ kinase activity was defined as the difference in $\left.{ }^{32} \mathrm{P}\right] \mathrm{ATP}$ incorporated in the presence and absence of phorbol dibutyrate and phosphatidylserine (PS), with $\mathrm{Ca}^{2+}$ present throughout. Protein kinase $\mathrm{C}$ activity was expressed in picomoles ${ }^{32} \mathrm{P}$ incorporated into histone per milligram membrane protein. Protein kinase $\mathrm{C}$ activity of the subcellular fractions was stable for at least $2 \mathrm{wk}$ and assays were performed within $5 \mathrm{~d}$ of preparation.

Phorbol binding assay. Protein kinase $\mathrm{C}$ in microvillus membranes was also quantified by $\left[{ }^{3} \mathrm{H}\right]$ phorbol dibutyrate binding (12). Reaction tubes contained $100 \mu \mathrm{g}$ of membrane protein from control or carbachol treated tissues, $4 \times 10^{-8} \mathrm{M}\left[{ }^{3} \mathrm{H}\right]$ phorbol dibutyrate $(12.4 \mathrm{Ci} / \mathrm{mol}), 75$ $\mathrm{mM} \mathrm{Mg}$ (acetate) $)_{2}, 5 \mathrm{mM} \mathrm{CaCl}{ }_{2}, 1.2 \mathrm{mg} / \mathrm{ml} \mathrm{BSA}, 96 \mu \mathrm{g} / \mathrm{ml} \mathrm{PS}$, and 20

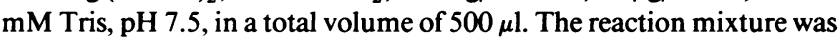
incubated at $0^{\circ} \mathrm{C}$ for $18 \mathrm{~h}$ and then filtered through Whatman Inc. 934-AH filters and washed four times with 8-ml aliquots of iced $0.15 \mathrm{M}$ $\mathrm{NaCl}, 0.05 \mathrm{M}$ Tris, $\mathrm{pH} 7.5 .\left[{ }^{3} \mathrm{H}\right] \mathrm{Phorbol}$ dibutyrate in the samples was then measured in a liquid scintillation counter. Nonspecific phorbol binding was determined with parallel samples containing phorbol dibutyrate $(3 \mu \mathrm{M})$ in addition to the $\left[{ }^{3} \mathrm{H}\right]$ phorbol dibutyrate. Specific phorbol binding was calculated as the difference in total and nonspecific binding. Duplicates of all samples were studied. Phorbol binding was expressed in picomoles per milligram membrane protein.

Measurement of diacylglycerol (DAG) ${ }^{1}$ content in microvillus membrane. Total DAG in the microvillus membrane was measured as previously described (13): lipids were extracted from microvillus membrane prepared from control tissue or from tissue exposed to $1 \mu \mathrm{M}$ carbachol or $1 \mu \mathrm{M} \mathrm{Ca}^{2+}$ ionophore for $10 \mathrm{~min}$, by mixing $4 \mathrm{vol}$ of chloroform/ methanol $(2 / 1: \mathrm{vol} / \mathrm{vol})$ with $1 \mathrm{vol}$ of membrane suspension with vortexing. The samples were centrifuged and the organic phase was dried under nitrogen. The resulting lipid samples were applied in parallel lanes to thin layer chromatography plates (prepared with a slurry of Silica Gel $60 \mathrm{H}$ in $\mathrm{H}_{2} \mathrm{O}$, spread to a thickness of $0.25 \mathrm{~mm}$ on a 20 $\times 20$-cm glass plate, air dried for at least $1 \mathrm{~h}$, and activated before use by heating to $120^{\circ} \mathrm{C}$ for $1 \mathrm{~h}$ ). The plates were developed in a solvent system containing heptane/diethyl ether/formic acid (90/40/3:vol/vol/ vol). Lipid spots were located with $I_{2}$ vapor. This chromatographic technique separated 1,2-diolein or 1,2-distearin from the phospholipids, 1,3-diolein, monolein, triolein, and cholesterol, all of which remained at the origin. Natural 1,2-DAG prepared by phospholipase C treatment of egg phosphatidylcholine migrated similarly to 1,2-diolein

1. Abbreviations used in this paper: DAG, 1,2 diacylglycerol; W13, $\mathrm{N}$-(4-aminobutyl)-5-chloro-2-naphthalenesulfonamide. 
and 1,2-distearin. In each experiment, standards containing 0, 1, 3, 5, and $10 \mathrm{nmol}$ of either 1,2-diolein or 1,2-distearin were run in lanes parallel to the experimental samples.

For quantitation, 1,2-DAG spots from experimental samples and standards were each scraped into clean glass test tubes. In addition, the origin from each lane was scraped into another glass test tube and total phospholipid phosphorus ( $\mathrm{Pi}$ ) was determined as described (14). To each tube containing 1,2-DAG, $200 \mu \mathrm{l}$ of hydrolysis solution (ethanol, $1 \mathrm{~N} \mathrm{NaOH}, 1.0 / 0.6: \mathrm{vol} / \mathrm{vol}$ ) was added. These were then incubated at $70^{\circ} \mathrm{C}$ for $90 \mathrm{~min}$. The resultant free glycerol was separated from the silica by alternate washing and centrifugation with $200 \mu \mathrm{l}$ of ethanol three times using a microfuge. The pooled ethanol washes were then dried under $\mathrm{N}_{2}$. The glycerol content was determined in each sample by measuring fluorometrically the conversion of NAD to NADH by glycerol dehydrogenase. The quantity of 1,2-DAG for each experimental sample was then determined from the standard curve and values were expressed as nanomoles of 1,2-DAG per micromole of total membrane Pi or per milligram membrane protein.

Marker enzyme assays. Marker enzymes for quantitation of membrane purification were: sucrase (15), for microvillus membranes; $\mathrm{Na}$ / $\mathrm{K}$ ATPase (16), for basolateral membranes; cytochrome $\mathrm{C}$ reductase (17), for endoplasmic reticulum; and monoamine oxidase (18), for mitochondria. Protein was measured using the Bradford procedure with ovalbumin as the standard (19).

$\mathrm{Na}^{+} / \mathrm{H}^{+}$exchange in villus cell brush border membrane vesicles. Rabbit ileal brush border vesicles were prepared by differential centrifugation and $\mathrm{Mg}$ precipitation as described (20). Tissue was incubated for $10 \mathrm{~min}$ in the absence or presence of $1 \mu \mathrm{M}$ carbachol in Ringer's-bicarbonate at $37^{\circ} \mathrm{C}$ as described for measurement of protein kinase $\mathrm{C}$, including the presence of $1 \mu \mathrm{M}$ indomethacin. All subsequent procedures in the membrane preparation were performed at $4^{\circ} \mathrm{C}$ except where noted. After incubation, the ileal villus cells were removed by light scraping with a glass slide. $10 \mathrm{~g}$ of each tissue (control and carbachol treated) were homogenized in $30 \mathrm{ml}$ of a buffer containing: $60 \mathrm{mM}$ mannitol, $2.4 \mathrm{mM}$ Tris $\mathrm{HCl}, \mathrm{pH} 7.1,1 \mathrm{mM}$ EGTA, $2.0 \mathrm{mM}$ Ca(gluconate) $)_{2}, 2 \mathrm{mM}$ dithiothreitol (DTT), $0.01 \%$ leupeptin, $0.32 \mathrm{mM}$ PMSF, $0.003 \mathrm{mM}$ phosphoramidone and $0.003 \mathrm{TIU} / \mathrm{ml}$ aprotinin. Homogenization consisted of 10 10-s bursts followed by 20 -s cooling intervals with a polytron homogenizer. The homogenates were treated with 10 $\mathrm{mM} \mathrm{MgCl}{ }_{2}$ for $15 \mathrm{~min}$ and then centrifuged at $12,000 \mathrm{~g}$ for $15 \mathrm{~min}$. The pellets were discarded and the supernatants were centrifuged at 27,000 $g$ for $30 \mathrm{~min}$. The pellets were resuspended in $25 \mathrm{ml}$ of a buffer containing: $60 \mathrm{mM}$ mannitol, $5 \mathrm{mM}$ EGTA, $6.0 \mathrm{mM} \mathrm{Ca}$ (gluconate) $)_{2}, 10 \mathrm{mM}$ Tris, $\mathrm{pH} 7.1,1 \mathrm{mM}$ DTT, and $0.01 \%$ leupeptin and homogenized with 10 strokes in a glass Teflon homogenizer. The $10 \mathrm{mM} \mathrm{MgCl}_{2}$ precipitation steps were repeated except the membrane was brought to $23^{\circ} \mathrm{C}$ for $15 \mathrm{~min}$, and the pellets homogenized in: $200 \mathrm{mM}$ mannitol, $5 \mathrm{mM}$ $\mathrm{Mg}$ (gluconate) $)_{2}, 2 \mathrm{mM}$ EGTA, $1 \mathrm{mM}$ DTT, $0.01 \%$ leupeptin, and 40 $\mathrm{mM}$ Mopso/Tris, $\mathrm{pH}$ 6.5. These suspensions were centrifuged at $27,000 \mathrm{~g}$ for $40 \mathrm{~min}$. The final two pellets, control and carbachol treated, were needle homogenized with a 1-ml syringe and 25-gauge needle in the same buffer and the suspensions brought to a protein concentration of $5 \mathrm{mg} / \mathrm{ml}$.

For transport studies, $350-\mu 1$ aliquots of the vesicles were mixed with $36 \mu$ l of the following (in final concentration): (a) $45 \mathrm{mM}$ mannitol, $45 \mu \mathrm{M} \mathrm{W13,}$ (b) $45 \mathrm{mM}$ mannitol, $45 \mu \mathrm{M} \mathrm{W13}, 542.4 \mu \mathrm{M} \mathrm{Ca}$ (gluconate) $)_{2}\left(1.5 \mu \mathrm{M}\right.$ free $\left.\mathrm{Ca}^{2+}\right), 1 \mu \mathrm{M}$ phorbol dibutyrate; $(c) 45 \mu \mathrm{M} \mathrm{W13}$, $542.4 \mu \mathrm{M} \mathrm{Ca}$ (gluconate) $)_{2}\left(1.5 \mu \mathrm{M}\right.$ free $\left.\mathrm{Ca}^{2+}\right), 1 \mu \mathrm{M}$ phorbol dibutyrate, $5.0 \mathrm{mM}$ ATP, $26 \mathrm{U} / \mathrm{ml}$ creatine kinase; (d) $45 \mu \mathrm{M} \mathrm{W13}, 542.4 \mu \mathrm{M}$ $\mathrm{Ca}$ (gluconate) ${ }_{2}\left(1.5 \mu \mathrm{M}\right.$ free $\left.\mathrm{Ca}^{2+}\right), 1 \mu \mathrm{M}$ phorbol, $5 \mathrm{mM}$ ATP, $26 \mathrm{U} / \mathrm{ml}$

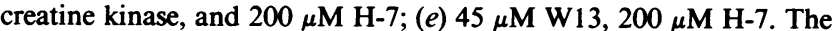
vesicles then were frozen in liquid nitrogen immediately after preparation. The following day, ${ }^{22} \mathrm{Na}^{+}$uptake or $\left[{ }^{3} \mathrm{H}\right]$ glucose uptake/equilibrium studies were performed. On the day of the experiment the samples were removed from the liquid $\mathrm{N}_{2}$ in a staggered fashion and allowed to thaw in an ice slurry for $60 \mathrm{~min} .10 \mathrm{mM}$ creatine phosphate was added to those samples containing creatine kinase and ATP and allowed 17 min at $4{ }^{\circ} \mathrm{C}$ to equilibrate before starting ${ }^{22} \mathrm{Na}^{+}$or $\left[{ }^{3} \mathrm{H}\right]$ glucose uptake measurements, which were terminated by rapid filtration on nitrocellulose $(45 \mu \mathrm{m})$ filters as previously described (20). Uptake of $\mathrm{Na}^{+}$was measured over $8 \mathrm{~s}$ after mixing the membranes with transport buffer, which is during the period when ${ }^{22} \mathrm{Na}^{+}$uptake, with and without a pH gradient, is linear with time in these vesicles $(2) .\left[{ }^{3} \mathrm{H}\right]$ Glucose uptake was measured at $60 \mathrm{~s}$ and $90 \mathrm{~min}$.

Results shown are mean \pm SEM. Statistical analyses were by Student's $t$ tests.

\section{Results}

Initial experiments were all performed starting with lightly scraped ileal mucosa. Characterization of subcellular fractions are summarized in Table I. Microvillus membranes of control tissues were purified 16-fold, and contained $\sim 6 \%$ of the total homogenate sucrase activity; these membranes had up to $0.9 \%$ of cytochrome $c$ reductase, $0.8 \%$ monamine oxidase, and $1.2 \%$ of $\mathrm{Na} / \mathrm{K}$ ATPase activity. Carbachol exposure did not affect either the degree of purification or the yield of the microvillus membranes.

The basolateral membranes were purified 14-fold. Their characterization included: Specific enrichment in activity of basolateral membrane relative to homogenate: $\mathrm{Na} / \mathrm{K}$ ATPase, 14.4-fold; sucrase, 0.9-fold; monoamine oxidase, 3.0-fold; cytochrome $c$ reductase 1.7-fold. Yield: $\mathrm{Na} / \mathrm{K}$ ATPase, 3.2\%; sucrase, $0.8 \%$; monoamine oxidase, $0.5 \%$; cytochrome $c$ reductase, $0.3 \%$.

Effect of carbachol and $\mathrm{Ca}^{2+}$ ionophore A23187 on ileal protein kinase $C$ activity and distribution. Microvillus membranes, basolateral membranes, and cytosol all contain protein kinase $C$ activity under basal conditions (Figs. 1 and 2 and Table I, and as reported previously [21]). In Figs. 1-3 the C kinase activity after $10 \mathrm{~min}$ exposure to carbachol and the time control are shown for homogenate, cytosol, microvillus membrane, and basolateral membrane. Protein kinase $\mathrm{C}$ activity was decreased in the cytosol and increased in the microvillus membranes by exposure to carbachol (Figs. 1 and 2). No

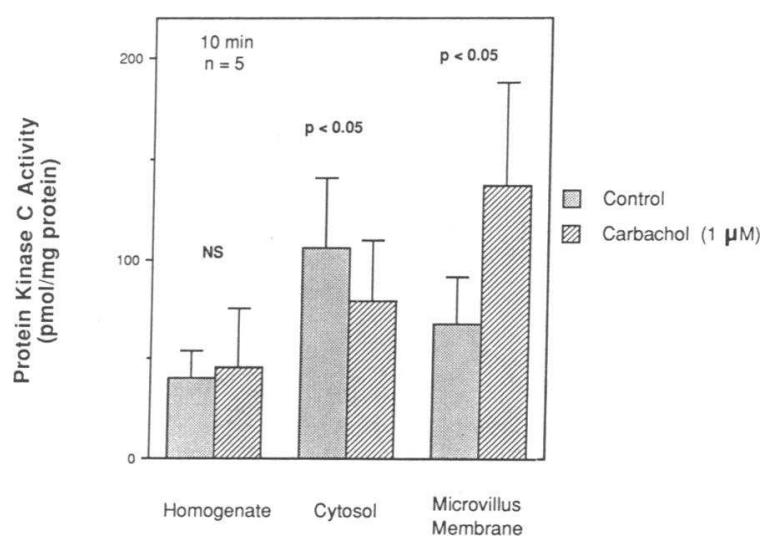

Figure 1. Effect of $10 \mathrm{~min}$ exposure to carbachol $(1 \mu \mathrm{M})$ on protein kinase $\mathrm{C}$ activity in homogenate, cytosol, and microvillus membranes of ileal villus cells. Ileal mucosa was exposed in vitro to carbachol and then predominantly villus cells were scraped off and subcellular fractionation performed. Protein kinase $\mathrm{C}$ was partially purified with DE- 52 before protein kinase $C$ activity determination in each fraction. Protein kinase is expressed as picomoles ${ }^{32} \mathrm{P}$ incorporated per milligram membrane or cytosol protein. The data represent the mean \pm SEM of five experiments. $P$ values above the bars are for the comparisons of control and carbachol exposed fractions (paired $t$ test). 


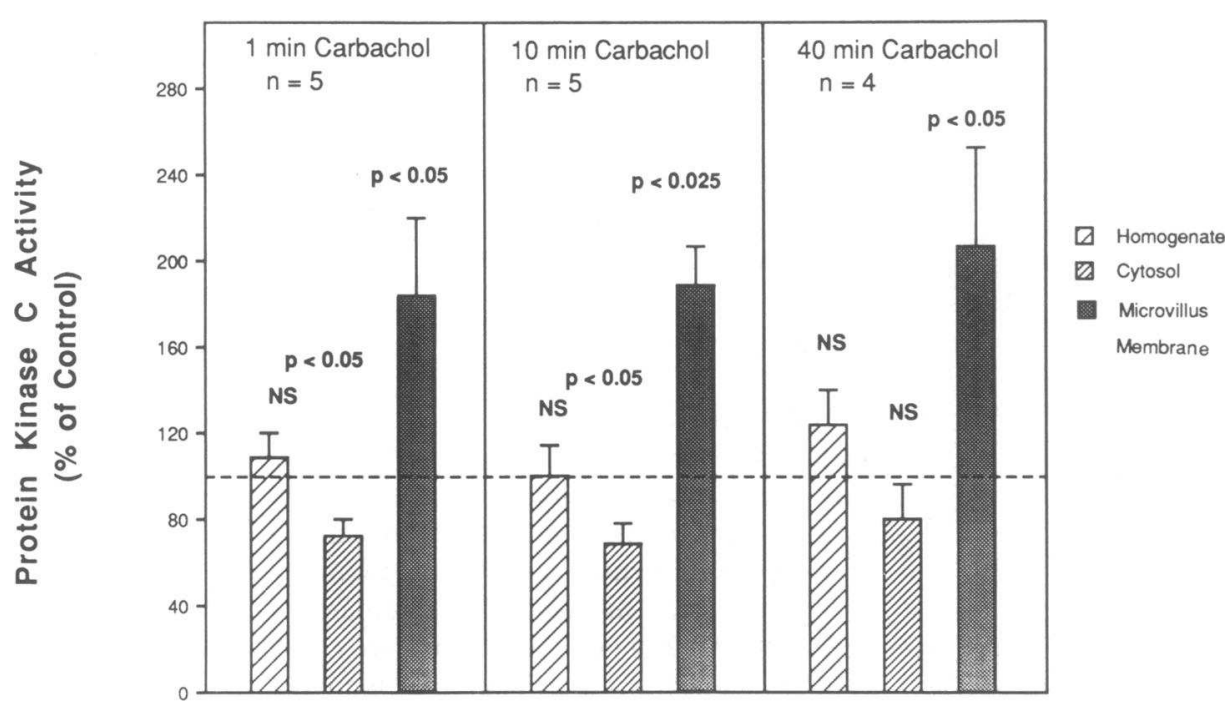

Figure 2. Effect of 1-, 10-, and 40-min exposures to carbachol $(1 \mu \mathrm{M})$ on protein kinase $\mathrm{C}$ activity in homogenate, cytosol, and microvillus membranes of ileal villus cells. The data are presented as percent of control, with the control set at $100 \%$ for each fraction in each experiment (horizontal dashed line). Mean control values in picomoles per milligram protein were, homogenate, $74 \pm 19$; cytosol, $162 \pm 44$; microvillus membrane, $113 \pm 34$. Results are the mean \pm SEM. $n$, number of experiments. $P$ values are for the comparison of carbachol exposed tissue with control for each subcellular fraction (paired $t$ test). changes occurred in the homogenates. In Fig. 2, time course studies are shown for the changes in homogenate, cytosol, and microvillus membrane protein kinase $\mathrm{C}$ activity after exposure of ileal mucosa to carbachol for 1,10 , and $40 \mathrm{~min}$. The results for each experiment are normalized to its time control and presented as percent changes. The effects of carbachol on protein kinase $\mathrm{C}$ activity in homogenate, cytosol, and microvillus membranes were similar at 1, 10, and 40 min (Fig. 2). Microvillus $\mathrm{C}$ kinase activity increased significantly between 84 and $105 \%$ above control. Cytosol $C$ kinase activity decreased significantly by $25-30 \%$ below control values after 1 and $10 \mathrm{~min}$ of exposure to carbachol, but the changes were no longer significant at $40 \mathrm{~min}$. Homogenate $\mathrm{C}$ kinase activity did not change. These results, obtained by measuring protein kinase $\mathrm{C}$ activity by histone IIIS phosphorylation and which showed an increase in $\mathrm{C}$ kinase activity in microvillus membranes were supported by measurements of the amount of protein kinase $C$ by $\left[{ }^{3} \mathrm{H}\right]$ phorbol binding. $10 \mathrm{~min}$ exposure to $1 \mu \mathrm{M}$ carbachol increased the amount of $\left[{ }^{3} \mathrm{H}\right]$ phorbol binding in microvillus membranes by $51 \pm 23 \%(n=5, P<0.05)$. Thus, the increased activity present in these membranes appears to be due to $C$ kinase translocation.
Fig. 3 shows similar studies performed with a highly purified basolateral membrane preparation, which was obtained by Percoll density gradient centrifugation. As shown in Fig. 3, $20 \mathrm{~s}$ and $1 \mathrm{~min}$ of exposure to carbachol caused no significant changes in basolateral membrane protein kinase $\mathrm{C}$ activity, whereas $10 \mathrm{~min}$ of exposure caused a significant decrease in protein kinase $C$ activity to $48 \pm 11 \%$ of control. Therefore, the increase in microvillus membrane $C$ kinase activity after carbachol treatment of the cells appears to be specific for that membrane fraction.

Because basolateral membranes prepared from scraped ileal mucosa could be contaminated with plasma membranes from nonepithelial cells, similar experiments were repeated, starting with isolated ileal villus epithelial cells. Both microvillus membranes and basolateral membranes were prepared from these dissociated cells. Microvillus membranes showed an increase in sucrase specific activity of 25 -fold with a total yield of $16.5 \%$. The characterization of the basolateral membranes included: Specific enrichment and activity of basolateral membrane relative to homogenate: $\mathrm{Na} / \mathrm{K}$ ATPase, 12.8 -fold; sucrase, 0.8-fold; cytochrome $c$ reductase, 1.7-fold. Yield: $\mathrm{Na}$ / K ATPase, $2.2 \%$; sucrase, $0.2 \%$; cytochrome $c$ reductase, $2.7 \%$.

Table I. Effect of Carbachol on Purification and Recovery of Marker Enzymes in Ileal Organelles

\begin{tabular}{|c|c|c|c|c|c|c|c|c|c|c|c|c|}
\hline & \multicolumn{4}{|c|}{ Homogenate } & \multicolumn{4}{|c|}{ Microvillus } & \multicolumn{4}{|c|}{ Crude basolateral } \\
\hline & \multicolumn{2}{|c|}{ Control } & \multicolumn{2}{|c|}{ Carbachol } & \multicolumn{2}{|c|}{ Control } & \multicolumn{2}{|c|}{ Carbachol } & \multicolumn{2}{|c|}{ Control } & \multicolumn{2}{|c|}{ Carbachol } \\
\hline & TA & SA & TA & SA & TA & SA & TA & SA & TA & SA & TA & SA \\
\hline $\begin{array}{l}\text { Sucrase } \\
\text { (microvillus membrane) }\end{array}$ & 11.8 & 0.03 & 12.7 & 0.03 & $\begin{array}{l}0.75 \\
(6.4 \%)\end{array}$ & $\begin{array}{r}0.48 \\
(\times 16)\end{array}$ & $\begin{array}{l}0.75 \\
(5.9 \%)\end{array}$ & $\begin{array}{r}0.49 \\
(\times 16)\end{array}$ & $\begin{array}{c}0.16 \\
(1.4 \%)\end{array}$ & $\begin{array}{r}0.05 \\
(\times 1.7)\end{array}$ & $\begin{array}{l}0.10 \\
(0.8 \%)\end{array}$ & $\begin{array}{r}0.02 \\
(\times 0.7)\end{array}$ \\
\hline $\begin{array}{l}\mathrm{Na} / \mathrm{K} \text { ATPase } \\
\quad \text { (basolateral membrane) }\end{array}$ & 1032 & 2.27 & 1180 & 2.80 & $\begin{array}{l}12 \\
(1.2 \%)\end{array}$ & $\begin{array}{r}3.95 \\
(\times 1.7)\end{array}$ & $\begin{array}{l}6 \\
(0.5 \%)\end{array}$ & $\begin{array}{r}2.82 \\
(\times 1.0)\end{array}$ & $\begin{array}{l}101 \\
(9.8 \%)\end{array}$ & $\begin{array}{r}5.70 \\
(\times 2.5)\end{array}$ & $\begin{array}{l}110 \\
(9.3 \%)\end{array}$ & $\begin{array}{r}7.00 \\
(\times 2.5)\end{array}$ \\
\hline $\begin{array}{l}\text { Monoamine oxidase } \\
\text { (mitochondria) }\end{array}$ & 65.3 & 0.16 & 58.8 & 0.14 & $\begin{array}{l}0.52 \\
(0.8 \%)\end{array}$ & $\begin{array}{r}0.18 \\
(\times 1.1)\end{array}$ & $\begin{array}{l}0.46 \\
(0.8 \%)\end{array}$ & $\begin{array}{r}0.16 \\
(\times 1.1)\end{array}$ & $\begin{array}{c}0.21 \\
(0.3 \%)\end{array}$ & $\begin{array}{r}0.03 \\
(\times 0.2)\end{array}$ & $\begin{array}{l}0.36 \\
(0.6 \%)\end{array}$ & $\begin{array}{r}0.06 \\
(\times 0.4)\end{array}$ \\
\hline $\begin{array}{l}\text { Cytochrome } c \text { reductase } \\
\text { (endoplasmic reticulum) }\end{array}$ & 15.8 & 0.04 & 13.8 & 0.03 & $\begin{array}{l}0.15 \\
(0.9 \%)\end{array}$ & $\begin{array}{r}0.07 \\
(\times 1.8)\end{array}$ & $\begin{array}{l}0.16 \\
(1.2 \%)\end{array}$ & $\begin{array}{r}0.08 \\
(\times 2.7)\end{array}$ & $\begin{array}{l}2.5 \\
(16 \%)\end{array}$ & $\begin{array}{r}0.16 \\
(\times 4.0)\end{array}$ & $\begin{array}{r}2.07 \\
(15 \%)\end{array}$ & $\begin{array}{r}0.12 \\
(\times 4.0)\end{array}$ \\
\hline
\end{tabular}

The results are given in units for total activity (TA) or in units per milligram protein for specific activity (SA). One unit is defined as enzyme activity hydrolyzing $1 \mu \mathrm{mol}$ of substrate per min. Numbers in parentheses under TA represent percent of total homogenate marker enzyme recovered in each fraction; numbers in parentheses under SA represent ratio of SA in fraction/SA in homogenate. 


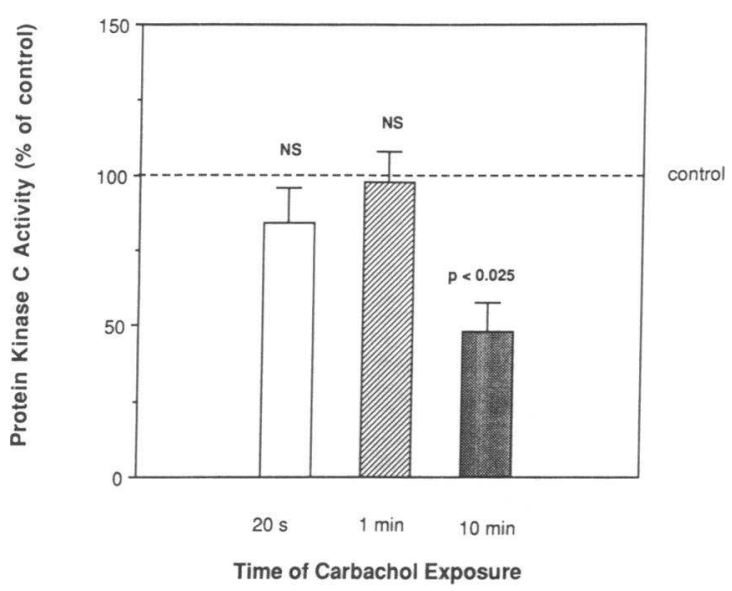

Figure 3. Effect of $20 \mathrm{~s}, 1$ and $10 \mathrm{~min}$ exposure to carbachol $(1 \mu \mathrm{M})$ on protein kinase $\mathrm{C}$ activity in purified basolateral membranes from scraped ileal villus cells. Protein kinase $\mathrm{C}$ activity from carbachol exposed ileal mucosa is plotted as percent of control \pm SEM, with the control set at $100 \%$ for each experiment (horizontal dashed line). Mean control values were $394 \pm 82 \mathrm{pmol} / \mathrm{mg}$ protein. Four to five separate experiments were performed at each time. The $P$ value represents comparison of control and carbachol exposed tissue.

An increase in microvillus membrane protein kinase $\mathrm{C}$ activity and a decrease in basolateral membrane protein kinase $\mathrm{C}$ activity was observed in membranes prepared from dissociated cells, very similar to that found with scraped ileal mucosa. In ileal villus cells exposed for $10 \mathrm{~min}$ to carbachol, microvillus membrane protein kinase $C$ activity was increased $91 \pm 31 \%$ ( $n$ $=4, P<0.05)$ compared with control; and basolateral membrane protein kinase $C$ activity was decreased by $58 \pm 13 \%$ compared with control $(n=3, P<0.05)$. Similar studies analyzing basolateral membrane were performed after exposure of isolated ileal villus cells to carbachol for $30 \mathrm{~s}$. Ileal basolateral membranes in carbachol exposed cells were significantly decreased by $11 \pm 3 \%$ compared with control, $n=4, P<0.025$.

Similar studies examined the effect of exposure of ileal mucosa to the $\mathrm{Ca}^{2+}$ ionophore $\mathrm{A} 23187$ for $10 \mathrm{~min}$, a period over which the ionophore decreases active ileal $\mathrm{NaCl}$ absorption. Exposing tissue to $1 \mu \mathrm{M} \mathrm{Ca}^{2+}$ ionophore $\mathrm{A} 23187$ for $10 \mathrm{~min}$, produced effects on cytosol and microvillus membrane similar to those observed with carbachol. There was a $70 \pm 21 \%$ increase in microvillus membrane protein kinase $\mathrm{C}$ activity and a $22 \pm 10 \%$ decrease in cytosol protein kinase $C$ activity. No significant changes occurred in whole homogenate $C$ kinase. However, in contrast to the carbachol-induced decrease in $\mathrm{C}$ kinase activity in the basolateral membranes, $10 \mathrm{~min}$ of $\mathrm{Ca}^{2+}$ ionophore exposure did not alter basolateral membrane protein kinase $C$ activity (Fig. 4).

Because elevating ileal $\left[\mathrm{Ca}^{2+}\right]_{i}$ caused protein kinase $\mathrm{C}$ translocation to microvillus membranes, the requirement for the continued presence of $\mathrm{Ca}^{2+}$ to retain the translocated protein kinase $\mathbf{C}$ was studied. Microvillus membranes made from tissue exposed for $10 \mathrm{~min}$ to carbachol, $\mathrm{Ca}^{2+}$ ionophore, or control conditions were extracted with $5 \mathrm{mM}$ EGTA and 5 mM EDTA before extraction with Triton X-100 and the C kinase activity extractable by both treatments was compared (Fig. 5). Little enzyme activity could be extracted from the membranes with divalent cation chelators indicating that al- though elevated $\mathrm{Ca}^{2+}$ plays a role in translocation of $\mathrm{C}$ kinase from cytosol to microvillus membranes, the effect is not reversed simply by removing $\mathrm{Ca}^{2+}$.

Effect of carbachol and $\mathrm{Ca}^{2+}$ ionophore on ileal microvillus membrane diacylglycerol (Fig. 6). Measurements of DAG (expressed as nanomoles per micromole total membrane phospholipid) were determined on microvillus membranes after $10 \mathrm{~min}$ exposure to control conditions, carbachol $(1 \mu \mathrm{M})$ or $\mathrm{Ca}^{2+}$ ionophore A23187 (1 $\mu \mathrm{M})$. Both carbachol and $\mathrm{Ca}^{2+}$ ionophore caused significant and similar increases in apical membrane DAG (microvillus DAG in nanomoles per micromole total Pi in control tissue, 4.2 $\pm 1.4(n=4)$; after exposure to carbachol, 8.9 \pm 3.7 ( $n=3, P$ compared to control $<0.05)$; and after $\mathrm{Ca}^{2+}$ ionophore, $8.3 \pm 2.1(n=4, P$ compared with control $<0.05)$. Similar conclusions were reached when the microvillus DAG was expressed per milligram microvillus membrane protein (data not shown). Total microvillus membrane phospholipid per milligram membrane protein was not significantly altered by carbachol or ionophore exposure (micromoles microvillus membrane total phospholipid per milligram membrane protein was $1.2 \pm 0.1 ; 1.2 \pm 0.2 ; 1.0 \pm 0.1$ in membranes of control, carbachol- and ionophore-treated ileum, respectively).

Functional significance of translocated protein kinase $C$ : effect on brush border $\mathrm{Na}^{+} / \mathrm{H}^{+}$exchange. Protein kinase $\mathrm{C}$ is present on the apical membranes of control and carbachol exposed ileal $\mathrm{Na}^{+}$absorbing cells. Studies were undertaken to determine the functional significance of the protein kinase $\mathrm{C}$ present on the apical membrane in control cells and after carbachol exposure. This was done by exposing ileum, in vitro, to carbachol for $10 \mathrm{~min}$ as described for the protein kinase $\mathrm{C}$ translocation studies, and then preparing right-side-out brush border membrane vesicles from control and carbachol exposed ileal villus cells. The vesicles were resuspended to contain the combinations described in the methods of $1.5 \mu \mathrm{M}$ free $\mathrm{Ca}^{2+}$; ATP, creatine phosphate, creatine kinase; phorbol dibutyrate; and the protein kinase $\mathrm{C}$ antagonist, $\mathrm{H}-7$. All vesicles contained $\mathrm{MgCl}_{2}$ and the $\mathrm{Ca}^{2+} /$ calmodulin (CaM) inhibitor W13 (45 $\mu \mathrm{M})$, the latter to be certain that any effect seen was not due to the endogenous $\mathrm{Ca}^{2+} / \mathrm{CaM}$-dependent protein kinase present in the vesicles (2). $\mathrm{Na}^{+}$uptake was measured in brush border vesicles from control and carbachol treated tissues. It can be calculated from the results shown in Table II, that addition of ATP, phorbol dibutyrate and $1.5 \mu \mathrm{M} \mathrm{Ca}^{2+}$ to vesicles from carbachol-treated tissue caused a $26 \%$ decrease in $\mathrm{Na}^{+} / \mathrm{H}^{+}$exchange $(n=4, P<0.05)$ and a $17 \%$ decrease in $\mathrm{Na}^{+}$uptake into the vesicles in the presence of an inside $\mathrm{pH}$ gradient $(P<0.05)$, whereas there was no effect on $\mathrm{Na}^{+}$uptake without a $\mathrm{pH}$ gradient. The presence of $\mathrm{Ca}^{2+}$, phorbol, and ATP together were necessary to observe this effect in carbachol-exposed tissue; $\mathrm{Ca}^{2+}$ plus phorbol dibutyrate in the absence of exogenous ATP did not alter $\mathrm{Na}^{+}$uptake. In the presence of $200 \mu \mathrm{M} \mathrm{H}-7, \mathrm{Ca}^{2+} /$ phorbol/ATP did not alter $\mathrm{Na}^{+} / \mathrm{H}^{+}$exchange in vesicles from carbachol-treated tissue (in studies done with the same vesicles as those used for the carbachol data shown in Table II, $\mathrm{Na}^{+} / \mathrm{H}^{+}$ exchange in vesicles exposed to phorbol/ $\mathrm{Ca}^{2+} / \mathrm{ATP}$ plus $\mathrm{H}-7$ was $211 \pm 15 \mathrm{pmol} / \mathrm{mg}$ protein- $8 \mathrm{~s}, n=4$; and in vesicles exposed to $\mathrm{H}-7$ alone was $208 \pm 14 \mathrm{pmol} / \mathrm{mg}$ protein-8 s, $n=4$ ). The data indicate that the carbachol-stimulated increase in $\mathrm{C}$ kinase activity in microvillus membranes has a functional role in regulation of apical membrane $\mathrm{Na}^{+} / \mathrm{H}^{+}$exchange.

It is important to note that despite the presence of $\mathrm{C}$ kinase in control brush border vesicles, there was no effect in these 


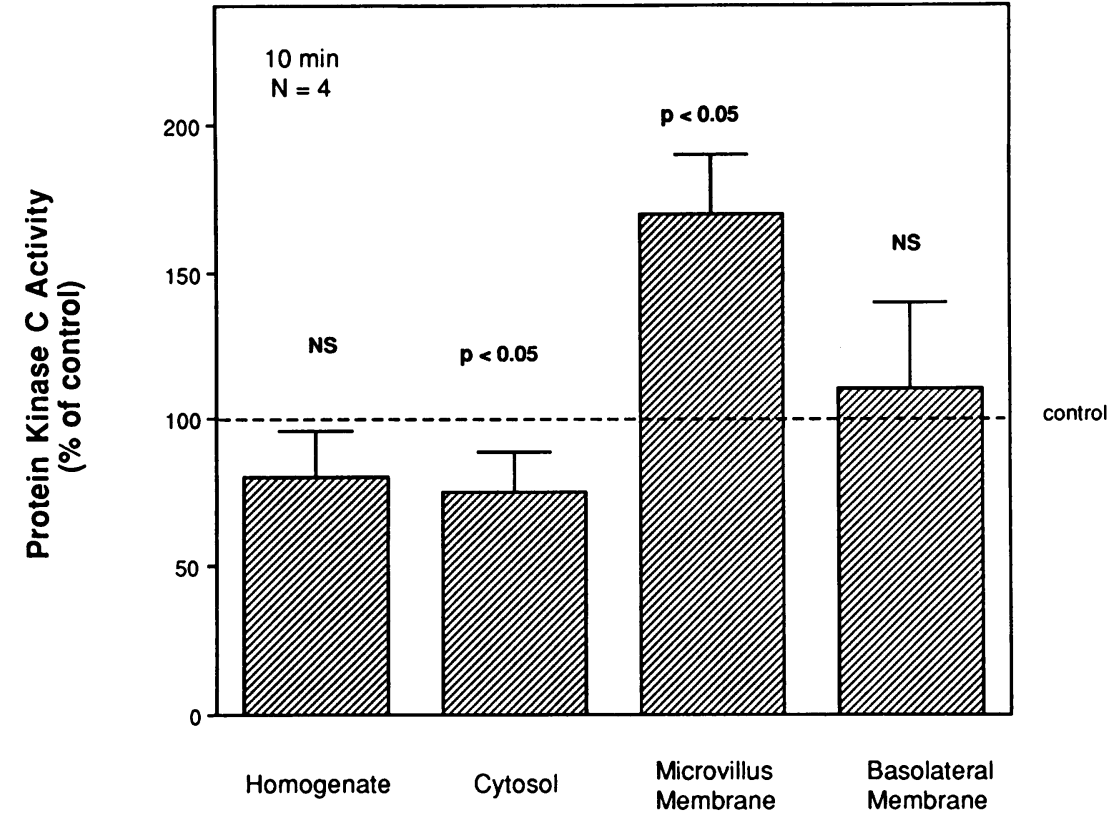

control vesicles of $\mathrm{Ca}^{2+} /$ phorbol/ATP on $\mathrm{Na}^{+}$uptake with or without a pH gradient or on $\mathrm{Na}^{+} / \mathrm{H}^{+}$exchange (Table II).

In contrast to the effect on $\mathrm{Na}^{+} / \mathrm{H}^{+}$exchange, glucose overshoot values at $1 \mathrm{~min}$ and equilibrium values, measured at 90 $\mathrm{min}$, in freeze thawed brush border vesicles were not significantly different in control and carbachol exposed tissue when treated with mannitol or with $\mathrm{Ca}^{2+}$ /phorbol/ATP (data not shown).
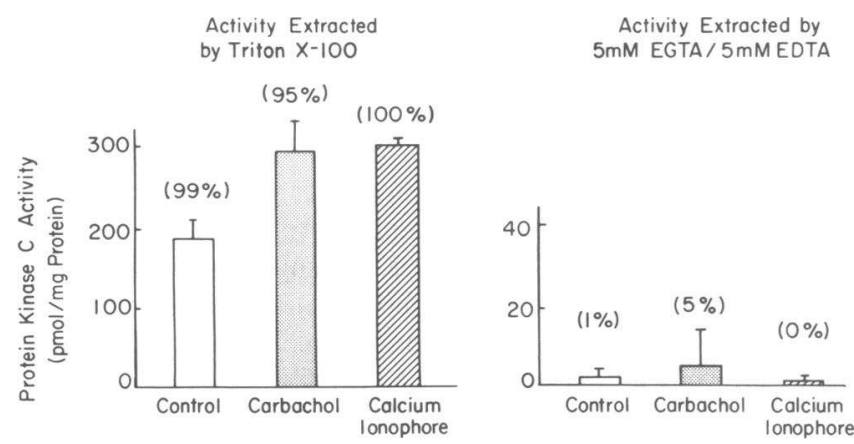

Figure 5. Lack of calcium dependence of protein kinase C already bound to microvillus membranes. Ileal mucosa was exposed to control conditions, $\mathrm{Ca}^{++}$ionophore $(1 \mu \mathrm{M})$ or carbachol $(1 \mu \mathrm{M})$ for 10 $\mathrm{min}$ in vitro and microvillus membranes were prepared. After preparation, microvillus membranes from control, carbachol-, and ionophore-treated tissues were first extracted with $5 \mathrm{mM}$ EDTA, $5 \mathrm{mM}$ EGTA, $20 \mathrm{mM}$ Tris, pH 7.5, for $30 \mathrm{~min}$ at $0^{\circ} \mathrm{C}$, pelleted by centrifugation, and the supernatant was saved for $\mathrm{C}$ kinase activity determination while the pellet was extracted with $0.3 \%$ Triton $\mathrm{X}-100$ for 30 min at $0^{\circ} \mathrm{C}$ and then assayed for $\mathrm{C}$ kinase. Protein kinase $\mathrm{C}$ in each of the extracts was partially purified with DE-52 cellulose and quantitated by histone IIIS phosphorylation. $C$ kinase activity extracted by Triton $\mathrm{X}-100$ is shown on the left and protein kinase $\mathrm{C}$ activity extracted by calcium chelators is shown on the right. Total $\mathrm{C}$ kinase activity is the sum of $C$ kinase in the Triton $X-100$ fraction plus that in the divalent chelator extract of each sample. The numbers in parentheses represent the percent of total activity of each sample which was extracted by cation chelators or by Triton X-100. The data represent the mean \pm SEM of three experiments.

\section{Discussion}

Figure 4. Effect of $10 \mathrm{~min}$ exposure to $\mathrm{Ca}^{2+}$ A23187 ionophore $(1 \mu \mathrm{M})$ on protein kinase $\mathrm{C}$ activity in subcellular fractions from ileal villus cells. C kinase activity was expressed as percent of control values with controls set at $100 \%$ in each subcellular fraction of each experiment (horizontal dashed line). Paired control and treated tissues were studied in each experiment. Control values in picomoles per milligram protein were homogenate, $66 \pm 7$; cytosol, $58 \pm 11$; microvillus membrane, $88 \pm 54$; basolateral membrane, $385 \pm 99$. Data represent the mean \pm SEM of four experiments. $P$ values above bars are for comparison of control and ionophore exposed tissue, in each subcellular fraction (paired $t$ test).

Previous studies have suggested that the effects of ionophore A23187 and carbachol, to inhibit ileal $\mathrm{NaCl}$ absorption, involve protein kinase $C$ because their effects are reversed by the isoquinolenesulfonamide $\mathrm{H}-7$ under conditions in which $\mathrm{H}-7$ is a relatively specific ileal villus cell protein kinase $C$ antagonist, and not an inhibitor of villus cell cyclic AMP, cyclic GMP, or $\mathrm{Ca}^{2+} / \mathrm{CaM}$-dependent protein kinases (3). The biochemical

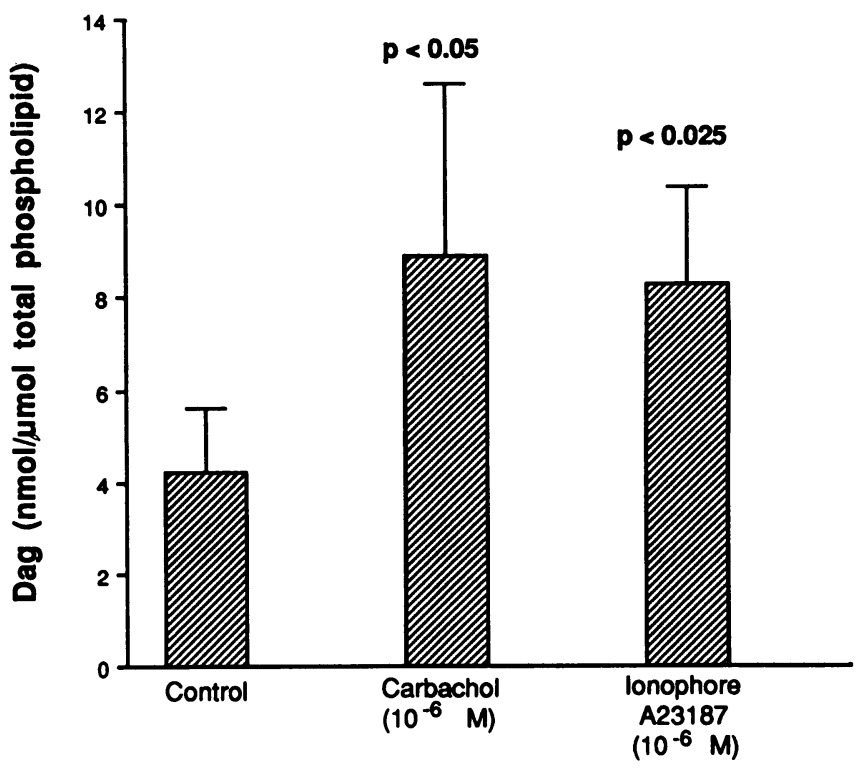

Figure 6. Carbachol $(1 \mu \mathrm{M})$ and $\mathrm{Ca}^{2+}$ ionophore $(1 \mu \mathrm{M})$ increase ileal microvillus membrane total diacylglycerol. Ileal mucosa was exposed in vitro to carbachol, A23187, or control conditions for $10 \mathrm{~min}$ and then predominantly villus cells scraped off, microvillus membranes prepared and total diacylglycerol determined and normalized to total membrane phospholipid. Results are mean \pm SEM of three experiments for carbachol and 4 for A23187. $P$ values represent comparisons with control (paired $t$ test). 
Table II. Effect of Exposure of Ileal Mucosa In Vitro to Carbachol and Subsequent Translocation of Protein Kinase C to the Brush Border on Brush Border $\mathrm{Na}^{+}$Uptake

\begin{tabular}{|c|c|c|c|}
\hline & \multicolumn{3}{|c|}{$\mathrm{Na}^{+}$uptake at $8 \mathrm{~s}$ (pmol/mg protein) } \\
\hline & $\begin{array}{c}\mathrm{Na}^{+} \text {uptake } \\
\text { with } \\
\text { pH gradient } \\
(A)\end{array}$ & $\begin{array}{l}\mathrm{Na}^{+} \text {uptake } \\
\text { without } \\
\text { pH gradient } \\
\text { (B) }\end{array}$ & $\begin{array}{l}\mathrm{Na}^{+} / \mathrm{H}^{+} \text {exchan } \\
\quad(C=A-B)\end{array}$ \\
\hline & pmol/mg protein & pmol/mg protein & $\mathrm{pmol} / \mathrm{mg}$ protei \\
\hline \multicolumn{4}{|l|}{ Vesicle treatment } \\
\hline \multicolumn{4}{|l|}{ Control } \\
\hline Mannitol & $276 \pm 31$ & $85 \pm 21$ & $191 \pm 26$ \\
\hline $\mathrm{Ca}^{2+} /$ phorbol & $287 \pm 39$ & $77 \pm 26$ & $209 \pm 24$ \\
\hline $\mathrm{Ca}^{2+} /$ phorbol/ATP & $260 \pm 26$ & $76 \pm 22$ & $184 \pm 27$ \\
\hline \multicolumn{4}{|l|}{ Carbachol } \\
\hline Mannitol & $282 \pm 17$ & $78 \pm 24$ & $204 \pm 15$ \\
\hline $\mathrm{Ca}^{2+} /$ phorbol & $279 \pm 21$ & $60 \pm 18$ & $219 \pm 18$ \\
\hline $\mathrm{Ca}^{2+} /$ phorbol/ATP & $234 \pm 26^{*}$ & $83 \pm 20$ & $151 \pm 21^{*}$ \\
\hline
\end{tabular}

${ }^{22} \mathrm{Na}^{+}$uptake was determined $(A)$ with an acid inside $\mathrm{pH}$ gradient $\left(\mathrm{pH}_{\mathrm{in}} 6.5 / \mathrm{pH}_{\text {out }} 8.0\right)$ and $(B)$ at $\mathrm{pH} 6.5$ inside and outside the vesicle; $\mathrm{Na}^{+} / \mathrm{H}^{+}$exchange was defined as the difference $(A$ minus $B$ ) in these rates of $\mathrm{Na}^{+}$uptake. Ileal mucosa was exposed in vitro for $10 \mathrm{~min}$ to $1 \mu \mathrm{M}$ carbachol or control, with both exposed to $1 \mu \mathrm{M}$ indomethacin. As described in Methods, brush border vesicles were prepared, loaded by freeze thawing with $\mathrm{Ca}^{2+}$ (free $\mathrm{Ca}^{2+} 1.5 \mu \mathrm{M}$ ), ATP, and phorbol dibutyrate in the presence of $\mathrm{W} 13$, the latter to eliminate the contribution exerted by the $\mathrm{Ca}^{2+} /$ calmodulin system. Data are means from four experiments. ${ }^{*} P<0.05$ comparing mannitol control to $\mathrm{Ca}^{2+} /$ phorbol/ATP in vesicles from carbachol exposed ileum.

mechanisms by which protein kinase $\mathrm{C}$ affects $\mathrm{Na}^{+}$absorption had not been determined. This study has shown that the changes in $\mathrm{NaCl}$ absorption caused by elevation of $\mathrm{Ca}^{2+}$ by both $\mathrm{Ca}^{2+}$ ionophore and carbachol are associated with the increases in DAG and protein kinase $C$ in the apical membranes of villus cells. It is likely these apical membrane changes are involved in regulation of $\mathrm{NaCl}$ absorption because the effect on brush border $\mathrm{Na}^{+} / \mathrm{H}^{+}$exchange caused by activation of protein kinase $\mathrm{C}$ was reversed by a protein kinase $\mathrm{C}$ antagonist. Another reason to suspect that it is the apical membrane protein kinase $\mathrm{C}$ which is relevant to regulation of transport is that carbachol and ionophore cause similar changes in $\mathrm{NaCl}$ absorption and apical membrane $\mathrm{C}$ kinase translocation, but have different effects on basolateral membrane $C$ kinase activity.

The facts that no detectable change in total tissue $\mathrm{C}$ kinase activity was observed to accompany the carbachol- and A23187-induced decrease in cytosol and increase in apical membrane protein kinase $\mathrm{C}$ activity, and that similar changes in microvillus membrane protein kinase $C$ were found by measuring enzyme activity and by measuring the amount of phorbol ester binding after carbachol exposure, suggest that the two secretagogues caused a redistribution of $\mathrm{C}$ kinase rather than a change in the total amount or activity. Prostaglandins do not appear to be involved in the mechanism of this translocation because the tissues were exposed to indomethacin, a cyclooxygenase inhibitor, during the secretagogue treatment.

An unusual aspect of the translocation of protein kinase $C$ in these polar epithelial cells is that the movement of the en- zyme appears to be specifically to the microvillus membrane, because no increase in the basolateral membrane activity occurred. In fact, by $30 \mathrm{~s}$ (using isolated villus epithelial cells) and 10 min after carbachol treatment, a significant decline in basolateral protein kinase $\mathrm{C}$ activity was found, whereas ionophore exposure for $10 \mathrm{~min}$ did not alter basolateral $\mathrm{C}$ kinase. The failure to detect $\mathrm{C}$ kinase movement to the basolateral membrane is relevant because the receptors for acetylcholine are located in this membrane (22). Whereas movement of protein kinase $\mathrm{C}$ to the plasma membrane is associated with signal transduction in many cell types, the concept of translocation to specific membranes and focal sites has only recently been suggested (23). The source of the protein kinase $C$ which appears on the apical membrane has not been definitely established, because both cytosol and basolateral membrane $C$ kinase decreased with carbachol exposure (see Table III). We favor cytosol being the source, as the increase in brush border $\mathrm{C}$ kinase activity is maximum within $1 \mathrm{~min}$ of exposure to carbachol, a time at which the cytosol decrease is also maximum, but a time at which there is only a minimal change in basolateral membrane $\mathrm{C}$ kinase activity. Also, carbachol and $\mathrm{Ca}^{++}$ionophore A23187 cause similar increases in brush border and decreases in cytosol protein kinase $\mathrm{C}$ activity, but only carbachol significantly alters basolateral $\mathrm{C}$ kinase activity. Not determined in these studies is the meaning of the decrease in basolateral $\mathrm{C}$ kinase activity $10 \mathrm{~min}$ after carbachol exposure. The balance sheet in Table III shows that this decrease in basolateral $\mathrm{C} \mathrm{ki-}$ nase activity is associated with the appearance of unaccounted for $C$ kinase activity; which suggests that the $C$ kinase may be translocating to other intracellular compartments.

After translocation to the microvillus membrane, the pro-

Table III. Protein Kinase C Activity per Gram Wet Weight

\begin{tabular}{lcc}
\hline & Control & 10 min Carbachol \\
\hline & $p m o l \%$ & $p m o l ~ \%$ \\
Homogenate & $5095(100)$ & $5511(100)$ \\
Microvillus membrane & $587(11.5)$ & $1118(20.3)$ \\
Basolateral membrane & $1544(30.3)$ & $1030(18.7)$ \\
Cytosol & $2822(55)$ & $2446(44.4)$ \\
Not accounted for & $(3.2)$ & $(16.6)$ \\
\hline
\end{tabular}

Balance sheet of protein kinase $\mathrm{C}$ activity in control conditions and 10 min after carbachol exposure. Shown are total protein kinase $\mathrm{C}$ activity in each fraction: homogenate, plasma membrane, and cytosol fractions per gram tissue wet weight; in parentheses are percent of total $\mathrm{C}$ kinase in each fraction. Each fraction was assayed for protein kinase $\mathrm{C}$ activity in picomoles incorporated into histone per milligram protein. To calculate total activity, specific activity was multiplied by the total protein for each fraction. To calculate total homogenate and cytosol protein per gram wet weight of mucosa, the protein concentration of homogenate or cytosol (milligrams per milliliter) was multiplied by the total volume of homogenate or cytosol, and divided by the wet weight of the mucosa used. To calculate total microvillus or basolateral membrane protein, the percentage marker enzyme recovered was first calculated, using sucrase and Na-K-ATPase, respectively. Then total microvillus or basolateral membrane protein per gram wet weight mucosa was calculated by dividing the total microvillus or basolateral membrane protein by the percentage recovery, and this divided by wet weight of mucosa. Data shown represent the mean result of three preparations. 
tein kinase $\mathrm{C}$ did not require $\mathrm{Ca}^{2+}$ for it to remain in the membrane, because treatment with EGTA and EDTA failed to extract it. These studies were performed on sheets of microvillus membrane which would have allowed detached $C$ kinase to be lost (8). Thus, the prolonged increased $\mathrm{C}$ kinase activity in the membrane after elevation of $\mathrm{Ca}^{2+}$ is not simply due to $\mathrm{a} \mathrm{Ca}^{2+}$ dependent absorption of enzyme to membrane, and additional factors other than $\mathrm{Ca}^{2+}$ must be involved in the binding. It has been shown by Wolfe et al. (24) that phorbol dibutyrate prevents the release of protein kinase $C$ from red blood cell membranes in the absence of $\mathrm{Ca}^{2+}$. Also, they suggested that an ATP-dependent phosphorylation reaction might be involved in the release of the enzyme from the membrane. In view of our results, in which DAG was found to increase in the apical membrane after exposure to carbachol and A23187, it would seem that the most likely additional factor is DAG. Of note, is a previous report of a $\mathrm{Ca}^{2+}$ ionophore elevating hepatic membrane DAG (25). Therefore, our data best fits an elevation in intracellular $\mathrm{Ca}^{2+}$ causing protein kinase $\mathrm{C}$ to move to the microvillus membrane. However, it is likely that protein kinase $\mathrm{C}$ remains there after $\mathrm{Ca}^{2+}$ is no longer elevated due to the generation of DAG.

The changes in $\mathrm{C}$ kinase activity with carbachol exposure were similar at 1,10 , and $40 \mathrm{~min}$, showing that the translocation of $\mathrm{C}$ kinase is both rapid and persistent, in line with persistent carbachol-induced changes in $\mathrm{NaCl}$ absorption which are seen in intact ileal tissue, in which inhibition of $\mathrm{NaCl}$ absorption is present by $10 \mathrm{~min}$ of exposure to carbachol with the effects persisting for at least $40 \mathrm{~min}$ (22, and Donowitz, M., and M. E. Cohen, unpublished observations). The time course of the carbachol-induced translocation of protein kinase $\mathrm{C}$, which is reported here, is different from that reported to occur in chicken small intestine in response to phorbol dibutyrate (26). In the latter, the phorbol ester treatment caused a transient $(90$ s) increase in microvillus protein kinase $\mathrm{C}$ activity which returned to control levels by $15 \mathrm{~min}$ (26). These differences could be due to the different species studied or to the different agonists used.

The $\mathrm{C}$ kinase translocated to the apical membrane of ileal $\mathrm{Na}^{+}$absorbing cells was functional, because addition of phorbol dibutyrate, ATP, and $\mathrm{Ca}^{2+}$ to carbachol-treated but not control vesicles inhibited $\mathrm{Na}^{+}$uptake and $\mathrm{Na}^{+} / \mathrm{H}^{+}$exchange. The effect was specific because there was no effect of the translocated $\mathrm{C}$ kinase, with or without $\mathrm{ATP}$, on $\mathrm{Na}^{+}$uptake in the absence of a pH gradient or on $\mathrm{Na}^{+}$-dependent glucose uptake. These data show that the newly translocated $\mathrm{C}$ kinase plays a role in the regulation of ileal villus cell $\mathrm{Na}^{+}$absorption and $\mathrm{Na}^{+} / \mathrm{H}^{+}$exchange but that the existing $\mathrm{C}$ kinase in membranes from control tissues does not have such a role. This difference between $\mathrm{C}$ kinase in control membranes, which is nonfunctional with respect to $\mathrm{Na}^{+} / \mathrm{H}^{+}$exchange, and the functional, translocated enzyme could be explained if the $C$ kinase which is translocated is a different isoform from that which is already present in the membrane. Alternatively, the $\mathrm{C}$ kinase present in the membrane under control conditions may not be in the correct location or configuration to affect the $\mathrm{Na}^{+} / \mathrm{H}^{+}$exchanger. It seems less likely, although possible, that a simple quantitative difference between the amounts of $\mathrm{C}$ kinase present in the membranes under control and stimulated conditions could provide an explanation.

The inhibition of brush border $\mathrm{Na}^{+} / \mathrm{H}^{+}$exchange by translocated protein kinase $\mathrm{C}$, in the presence of $\mathrm{Ca}^{2+}$, phorbol ester, and ATP, is the most direct demonstration that protein kinase $\mathrm{C}$ is involved in the control of ileal $\mathrm{Na}^{+}$absorption by inhibiting the brush border $\mathrm{Na}^{+} / \mathrm{H}^{+}$exchanger. Initially, protein kinase $\mathrm{C}$ was suggested as stimulating all $\mathrm{Na}^{+} / \mathrm{H}^{+}$exchangers. Now, with few exceptions (27), protein kinase $\mathrm{C}$ has been found to inhibit both intestinal and renal apical membrane $\mathrm{Na}^{+} / \mathrm{H}^{+}$exchangers but to stimulate their basolateral $\mathrm{Na}^{+} / \mathrm{H}^{+}$ exchangers $(3,26,28-30)$. Whether it is the location in the plasma membrane, the molecular nature of the $\mathrm{Na}^{+} / \mathrm{H}^{+}$exchangers, or the subtype of protein kinase $\mathrm{C}$ involved which accounts for this differential regulation remains unknown.

\section{Acknowledgments}

We acknowledge the expert secretarial assistance of Ms. Ann Harlow Sheppe and Ms. Judith Hariton and the expert technical assistance of Ms. Mari Payne. We are grateful to Dr. Cynthia S. Weikel for advice concerning the phorbol binding studies.

These studies were supported by a National Institutes of Health (NIH) Research Career Development Award K04-00588, and NIH grants R01 DK26523, R01 DK31667, R01 DK33010, and P30 DK39428.

\section{References}

1. Donowitz, M., and M. J. Welsh. $1986 . \mathrm{Ca}^{++}$and cyclic AMP in regulation of intestinal Na, K, and $\mathrm{Cl}$ transport. Annu. Rev. Physiol. 48:135-150.

2. Rood, R. P., E. Emmer, J. Wesolek, J. McCullen, Z. Husain, M. E. Cohen, R. S. Braithwaite, H. Murer, G. W. G. Sharp, and M. Donowitz. 1988. Regulation of the rabbit ileal brush-border $\mathrm{Na} / \mathrm{H}$ exchanger by an ATP-requiring $\mathrm{Ca}^{++}$/ calmodulin-mediated process. J. Clin. Invest. 82:1091-1097.

3. Donowitz, M., M. E. Cohen, M. Gould, and G. W. G. Sharp. 1989. Elevated intracellular $\mathrm{Ca}^{++}$acts through protein kinase $\mathrm{C}$ to regulate rabbit ileal $\mathrm{NaCl}$ absorption: evidence for sequential control by $\mathrm{Ca}^{++} /$calmodulin and protein kinase C. J. Clin. Invest. 84:1509-1517.

4. Wooten, M. W., and R. W. Wrenn. 1985. Redistribution of phospholipid/ calcium-dependent protein kinase and altered phosphorylation of its soluble and particulate substrate proteins in phorbol ester-treated rat pancreatic acini. Cancer Res. 45:3912-3917.

5. TerBush, D. R., and R. W. Holz. 1986. Effects of phorbol esters, diglyceride, and cholinergic agonists on the subcellular distribution of protein kinase $C$ in intact or digitonin-permeabilized adrenal chromaffin cells. J. Biol. Chem. 261:17099-17106.

6. Halsey, D. L., P. R. Girard, J. F. Kuo, and P. J. Blackshear. 1987. Protein kinase $\mathrm{C}$ in fibroblasts: characteristics of its intracellular location during growth and after exposure to phorbol esters and other mitogens. J. Biol. Chem. 262:2234-2243.

7. Ho, A. K., T. P. Thomas, C. L. Chik, W. B. Anderson, and D. C. Klein 1988. Protein kinase $C$ : subcellular redistribution of protein kinase $C$ is involved in potentiation of $\beta$-adrenergic stimulation of pineal cAMP and cGMP by $\mathrm{K}^{+}$and A23187. J. Biol. Chem. 263:9292-9297.

8. Donowitz, M., M. E. Cohen, R. Gudewich, L. Taylor, and G. W. G. Sharp. 1984. $\mathrm{Ca}^{2+}$-Calmodulin, cyclic AMP-, and cyclic GMP-induced phosphorylation of proteins in purified microvillus membranes of rabbit ileum. Biochem. J. 219:573-581.

9. Scalera, V., C. Storelli, C. Storelli-Joss, W. Haase, and H. Murer. 1980. A simple and fast method for the isolation of basolateral plasma membranes from rat small intestinal epithelial cells. Biochem. J. 186:177-181.

10. Kandel, G., A. Donohue-Rolfe, M. Donowitz, and G. T. Keusch. 1989 Pathogenesis of Shigella diarrhea. Selective targeting of Shiga toxin to villus cells of rabbit jejunum explains the effect of the toxin on intestinal electrolyte transport. J. Clin. Invest. 84:1809-1817.

11. Weiser, M. M. 1973. Intestinal epithelial cell surface membrane glycoprotein synthesis. I. An indicator of cellular differentiation. J. Biol. Chem. 248:25362541 .

12. Weikel, C. S., J. J. Sando, and R. L. Guerrant. 1985. Stimulation of porcine jejunal ion secretion in vivo by protein kinase-C activators. J. Clin. Invest. 76:2430-2435.

13. Pandol, S. J., and M. S. Schoeffield. 1986. 1,2-Diacylglycerol, protein kinase $C$, and pancreatic enzyme secretion. J. Biol. Chem. 261:4438-4444.

14. Pandol, S. J., M. W. Thomas, M. S. Schoeffield, G. Sachs, and S. Muallem. 1985. Role of calcium in cholecystokinin-stimulated phosphoinositide breakdown in exocrine pancreas. Am. J. Physiol. 248:G551-G560. 
15. Messer, M., and A. Dahlquist. 1966. A one-step ultramicro method for the assay of intestinal disaccharidases. Anal. Biochem. 14:376-392.

16. Albers, R. W., A. G. Rodriguez, and E. DeRobertis. 1965. Sodium-potassium-activated ATPase and potassium-activated p-nitrophenylphosphatase: a comparison of their subcellular localizations in rat brain. Proc. Natl. Acad. Sci. USA. 53:557-563.

17. Omura, R., and J. Takesue. 1970. A new method for simultaneous purification of cytochrome $b_{5}$ and NADPH-cytochrome $C$ reductase from rat liver microsomes. J. Biochem. (Tokyo). 67:249-258.

18. Wurtman, R. S., and J. Axelrod. 1963. A sensitive and specific assay for the estimation of monoamine oxidase. Biochem. Pharmacol. 12:1439-1441.

19. Bradford, M. M. 1976. Rapid and sensitive method for the quantitation of microgram quantities of protein utilizing the principal of protein-dye binding. Anal. Biochem. 72:248-254.

20. Donowitz, M., E. Emmer, J. McCullen, L. H. Reinlib, M. E. Cohen; R. P. Rood, J. Madara, G. W. G. Sharp, H. Murer, and K. Malstrom. 1987. Freezethaw and high voltage discharge allow macromolecule uptake into ileal brushborder vesicles. Am. J. Physiol. 252:G723-G735.

21. Velasco, G., C. F. Iglesias, P. Dominguez, F. Barros, S. Gascon, and P. S Lazo. 1986. Protein kinase $C$ from small intestine epithelial cells. Biochem. Biophys. Res. Commun. 139:875-882.

22. Tapper, E. T., D. W. Powell, and S. M. Morris. 1978. Cholinergic-adrenergic interaction on intestinal ion transport. Am. J. Physiol. 235:E402-E409.
23. Pontremoli, S., E. Melloni, B. Sparatore, M. Michetti, F. Salamino, and B. L. Horecker. 1990. Isozymes of protein kinase $\mathrm{C}$ in human neutrophils and their modification by two endogenous proteinases. J. Biol. Chem. 265:706-712.

24. Wolf, M., P. Cuatrecasas, and N. Sahyoun. 1985. Interaction of protein kinase $\mathrm{C}$ with membranes is regulated by $\mathrm{Ca}^{2+}$, phorbol esters, and ATP. J. Biol. Chem. 260:15718-15722.

25. Bocckino, S. B., P. F. Blackmore, and J. H. Exton. 1985. Stimulation of 1,2-diacylglycerol accumulation in hepatocytes by vasopressin, epinephrine, and angiotensin II. J. Biol. Chem. 260:14201-14207.

26. Chang, E. B., N. S. Wang, and M. C. Rao. 1985. Phorbol ester stimulation of active anion secretion in intestine. Am. J. Physiol. 249:C356-C361.

27. Weinman, E. J., W. P. Dubinsky, K. Fisher, D. Steplock, Q. Dinh, L. Chang, and S. Shenolikar. 1988. Regulation of reconstituted renal $\mathrm{Na}^{+} / \mathrm{H}^{+}$ex changer by calcium-dependent protein kinases. J. Membr. Biol. 103:237-244.

28. Donowitz, M., H. Y. Cheng, and G. W. G. Sharp. 1986. Effects of phorbol esters on sodium and chloride transport in rat colon. Am. J. Physiol. 251:G509G517.

29. Ma, A. I., C. M. Tse, A. J. M. Watson, M. Montrose, S. A. Levine, C Sardet, J. Pouyssegur, and M. Donowitz. 1991. Expression and extracellular regulation of the rabbit ileal villus basolateral membrane $\mathrm{Na}^{+} / \mathrm{H}^{+}$exchanger in a fibroblast. Gastroenterology. 100: 695a. (Abstr.)

30. Cassavola, V., C. Helmle-Kolb, and H. Murer. 1989. Separate regulatory control of apical and basolateral $\mathrm{Na}^{+} / \mathrm{H}^{+}$exchange in renal epithelial cells. Biochem. Biophys. Res. Commun. 165:833-837. 